\title{
Analisis Pengembangan Ekspor Cengkeh Indonesia
}

\author{
Ely Nurhayati ${ }^{1}$, Sri Hartoyo ${ }^{2}$, Sri Mulatsih ${ }^{2}$ \\ ${ }^{1}$ Mahasiswa Pascasarjana, Departemen Ilmu Ekonomi, Fakultas Ekonomi dan Manajemen, \\ Institut Pertanian Bogor, Indonesia \\ ${ }^{2}$ Staf Pengajar, Departemen Ilmu Ekonomi, Fakultas Ekonomi dan Manajemen, Institut \\ Pertanian Bogor, Indonesia \\ Korespondensi: haya.jundullah@gmail.com
}

[diterima: 20 Juni 2018 - revisi 30 Juni 2018 - diterbitkan daring: 20 Juli 2018$]$

\begin{abstract}
ABSTRAK
Ekspor merupakan komponen penting dalam perekonomian. Semakin tinggi kinerja ekspor, semakin besar pula dampak positifnya terhadap perekonomian. Sejak tahun 2012 hingga tahun 2016, ekspor Indonesia terus menurun, sehingga Indonesia perlu meningkatkan kembali ekspornya. Salah satu komoditas yang potensial dikembangkan adalah cengkeh. Penelitian ini menganalisis pengembangan ekspor cengkeh Indonesia dengan mencari tahu daya saing cengkeh, serta faktor yang mempengaruhi ekspornya. Metode yang digunakan adalah RCA, EPD, X-Model, dan Gravity. Hasil analisis menemukan bahwa pasar yang optimis dikembangkan adalah Pakistan, Jerman, Italia dan Amerika. Pasar yang potensial dikembangkan adalah pasar Malaysia, Vietnam, Thailand, Prancis dan Belanda. Faktor yang mempengaruhi ekspor cengkeh Indonesia adalah PDB per kapita, harga ekspor, jarak ekonomi dan tarif.
\end{abstract}

Kata kunci: Cengkeh, Ekspor, EPD, Model Gravity, RCA

\begin{abstract}
Exports are an important component of the economy. The higher export performance, the greater positive impact on the economy. From 2012 to 2016, Indonesia's exports continue to decline, so Indonesia needs to boost its exports again. One of the potential commodities developed is cloves. This study analyzes the development of Indonesian clove exports by finding out the competitiveness of cloves, as well as factors affecting its exports. The methods used are RCA, EPD, X-Model, and Gravity. The results of the analysis found that an optimistic market developed is Pakistan, Germany, Italy and United State of America. Potential markets to be developed are Malaysia, Vietnam, Thailand, France and Netherlands markets. Factors affecting Indonesian clove exports are GDP per capita, export price, economic distance and tariff.
\end{abstract}

Keywords: Clove, EPD, Export, Gravity Model, RCA

JEL Classification: C23, F10, F13 


\section{PENDAHULUAN}

Ekspor merupakan salah satu komponen yang menjadi perhatian penting dalam ekonomi suatu negara. Secara eksplisit ekspor digunakan sebagai salah satu komponen dalam perhitungan Produk Domestik Bruto (PDB), sehingga ekspor menjadi salah satu faktor yang paling berkontribusi terhadap PDB. Semakin tinggi kinerja ekspor negara, semakin besar pula dampak positifnya terhadap perekonomian negara. Selain meningkatkan pertumbuhan, peningkatan ekspor juga akan mendorong pergerakan perekonomian negara, sebab ekspor negara dapat menarik banyak investasi, meningkatkan penyerapan tenaga kerja, dan memaksimalkan pemanfaatan sumber daya alam lokal.

Berdasarkan data Badan Pusat Statistik, kinerja ekspor total Indonesia sejak tahun 2007 hingga 2016 terus mengalami fluktuasi. Setelah pada tahun 2008 nilainya meningkat menjadi 137.020 424.402 USD dari nilai ekspor tahun 2007 yang hanya senilai 114.100 .890 .751 USD, kemudian pada tahun 2009 nilai ekspor kembali Indonesia mengalami penurunan menjadi 116.510.026.081 USD. Pada tahun 2010 dan 2011 ekspor Indonesia kembali meningkat, namun sejak tahun 2012 hingga tahun 2016 ekspor Indonesia kembali mengalami penurunan, dari 190.031.845.244 USD pada tahun 2012 turun menjadi 144.489 825.811 USD pada tahun 2016. Apabila kondisi ini terus dibiarkan, tentu akan dapat mengancam perekonomian negara, pada khususnya neraca perdagangan.

Selain ekspor, impor pun menjadi faktor lain yang dapat mempengaruhi perekonomian negara. Tujuan aktifitas impor pada dasarnya adalah untuk memenuhi kebutuhan negara yang tidak terpenuhi oleh produksi dalam negeri. Namun demikian, tujuan baik aktifitas impor tersebut dapat berdampak negatif pada perekonomian negara bila nilai impor negara lebih tinggi dari nilai ekspornya. Hal inilah yang sempat terjadi di Indonesia. Sejalan dengan penurunan nilai ekspor, sejak tahun 2013 nilai impor Indonesia pun juga mengalami penurunan. Namun demikian besarnya penurunan nilai impor Indonesia ini tidak sebesar nilai penurunan ekspornya. Kondisi ini menyebabkan Indonesia mengalami defisit neraca perdagangan pada tahun 2012 hingga tahun 2014.

Pada tahun 2015 dan 2016 lebih dari $50 \%$ nilai ekspor Indonesia masih tergantung pada negara-negara tujuan ekspor utama. Negara-negara tujuan ekspor utama Indonesia tersebut adalah Jepang, Cina, Amerika Serikat, Singapura, India dan Malaysia. Ketergantungan Indonesia yang besar terhadap pasar utama ini sangat beresiko bagi aktivitas ekspor, terutama bila di negara tersebut terjadi guncangan ekonomi. Bila negaranegara tersebut mengalami guncangan ekonomi, hal tersebut tentu akan mempengaruhi stabilitas ekspor Indonesia ke negara tersebut. Apalagi bila melihat bahwa negara-negara tujuan utama ekspor Indonesia adalah negara-negara besar, yaitu negara yang cenderung rentan terhadap terjadinya krisis global. Sebagai contoh, terjadinya perlambatan ekonomi dunia pada tahun 2008, menyebabkan penurunan permintaan impor dari Indonesia, terutama negara tujuan ekspor utama seperti Amerika Serikat, Jepang, China, dan Malaysia. Pada saat itu, nilai ekspor ke 5 pasar utama menurun dari 50,7\% di tahun 2004 menjadi 48,0\% di 2009 (BPS, 2010).

Pada tahun 2015 dan 2016, lebih dari lima puluh persen dari total nilai ekspor Indonesia masih terkonsentrasi ke negara-negara tujuan ekspor utama. Negara-negara besar yang terdiri dari Jepang, Cina, dan Amerika Serikat berada 
diurutan teratas sebagai negara yang paling mendominasi ekspor Indonesia, kemudian disusul oleh Singapura, India, dan Malaysia. Kontribusi keenam negara tersebut terhadap ekspor Indonesia pada tahun 2015 adalah sebesar 52,9 persen dan pada tahun 2016 sebesar 53,6 persen. Sedangkan negara-negara lain yang tidak termasuk dalam enam negara tujuan ekspor utama tersebut hanya berkontribusi sekitar 40 persen saja dari total nilai ekspor Indonesia. Hal ini mencerminkan bahwa potensi ekspor Indonesia ke negara lain yang tidak termasuk dalam negara tujuan utama ekspor masih belum dimaksimalkan. Padahal tentunya negaranegara tersebut sangat berpotensi untuk dijadikan pasar tujuan ekspor.

Melihat kondisi tersebut, tentunya Indonesia perlu melakukan upaya-upaya strategis untuk kembali meningkatkan nilai ekspornya serta menghindari terjadinya defisit neraca perdagangan. Salah satu upaya yang dapat dilakukan Indonesia untuk meningkatkan nilai ekspor adalah dengan melakukan pengembangan ekspor.

Dalam rangka upaya meningkatkan ekspor, pada dasarnya Indonesia memiliki banyak pilihan produk yang potensial untuk dikembangkan. Sebagai negara agraris, produk-produk pertanian tentu menjadi produk yang dapat diandalkan untuk meningkatkan kinerja ekspor. Salah satu produk potensial Indonesia yang dapat dimaksimalkan untuk meningkatkan ekspor adalah produk rempah-rempah (Kemendag 2017). Dari berbagai macam komoditas rempah yang dihasilkan, cengkeh merupakan salah satu komoditas rempah terbaik Indonesia.

Berdasarkan data produksi Kementan (2014), Indonesia adalah negara yang menghasilkan cengkeh terbesar di dunia. Produksi cengkeh Indonesia pada tahun 2012 adalah sebesar 99.890 ton, setara dengan 70,99 persen dari total produksi cengkeh dunia. Berdasarkan rata-rata produksi cengkeh dunia tahun 2008 hingga 2012, Indonesia juga merupakan produsen cengkeh terbesar di dunia. Rata-rata kontribusi Indonesia terhadap produksi cengkeh dunia pada periode tersebut adalah sebesar 79,25 persen per tahun. Demikian pula dengan produksi cengkeh Indonesia bila dibandingkan dengan produksi cengkeh negara lain di kawasan ASEAN. Produksi cengkeh Indonesia juga mendominasi produksi cengkeh di ASEAN, pada tahun 2012 Indonesia berkontribusi sebesar 99,66 persen produksi cengkeh ASEAN (Kementan, 2014). Besarnya produksi cengkeh Indonesia merupakan modal yang besar bagi pengembangan ekspor cengkeh Indonesia di pasar internasional. Selain produksi, kualitas cengkeh Indonesia juga merupakan yang terbaik di pasar internasional. Standar mutu produksi Indonesia cengkeh sangatlah tinggi.

Bila dilihar dari data produksi dan luas lahan, tren perkembangan produksi dan luas lahan cengkeh Indonesia beberapa tahun belakangan cenderung meningkat. Peningkatan tersebut tentu menjadi penopang bagi ekspor cengkeh Indonesia.

Tabel 1 Produksi dan Luas Lahan Cengkeh Indonesia (ton)

\begin{tabular}{ccc}
\hline Tahun & Produksi (ton) & Luas Lahan (ha) \\
\hline 2010 & 98.386 & 470.041 \\
2011 & 72.246 & 485.193 \\
2012 & 99.890 & 493.888 \\
2013 & 109.699 & 501.843 \\
2014 & 122.134 & 510.174 \\
\hline
\end{tabular}

Sumber : Kementerian Pertanian 
Berdasarkan uraian di atas, maka dirasa perlu bagi Indonesia untuk melakukan pengembangan ekspor. Salah satu produk yang berpotensi dikembangkan ekspornya adalah cengkeh. Karenanya pada kesempatan kali ini peneliti tertarik untuk mengkaji lebih dalam tentang pengembangan ekspor cengkeh Indonesia.

\section{TINJAUAN PUSTAKA}

\section{Daya Saing}

Peningkatan aktifitas perdagangan yang dilakukan melalui pengembangan ekspor dapat mendorong ekspor negara menjadi lebih baik, untuk dapat melakukan pengembangan ekspor, negara perlu memperhatikan daya saing produk yang diperdagangkannya. Menurut terminologinya daya saing didefinisikan sebagai produktifitas. Berdasarkan definisi world economic forum daya saing adalah kumpulan institusi, kebijakan dan faktorfaktor yang menentukan tingkat produktifitas suatu negara. Dalam perdagangan internasional, daya saing juga dapat didefinisikan sebagai kemampuan suatu komoditas dari suatu negara untuk dapat memasuki serta bertahan di pasar internasional. Suatu produk yang banyak diminati di pasar internasional sehingga mampu memasuki serta bertahan di pasar internasional, produk tersebut dapat dikatakan sebagai produk yang memiliki daya saing. Sedangkan menurut teori Porter (1994), daya saing adalah produktifitas yang merupakan bagian dari output yang dihasilkan oleh tenaga kerja, kapital, dan sumber daya alam di suatu negara. Suatu negara akan memperoleh keunggulan dalam daya saing jika perusahaan kompetitif dan mampu meningkatkan kemampuannya serta melakukan inovasi dalam industri perdagangan. Daya saing suatu negara juga dapat tergantung pada perubahan dari perilaku dasar permintaan, tingkat kompetisi, dan kemampuan dasar yang dimiliki oleh industri di suatu negara, karenanya daya saing bersifat dinamis dan berfluktuasi dari waktu ke waktu. Karena sifatnya yang berfluktuasi ini, negara perlu terus melakukan monitoring terhadap keunggulan produkproduknya.

Dalam penelitian Hermawan (2015) tentang daya saing rempah Indonesia di pasar ASEAN periode pra dan pasca krisis ekonomi global, penelitian tersebut menggunakan metode Revealed Comparative Advantage (RCA), IntraIndustry Trade (IIT), Index of Export Overlap (IEO), dan Index of Export Similarity (IES) untuk mengukur daya saing rempah. Berdasarkan hasil perhitungan RCA, daya saing pasar rempah di ASEAN-5 didominasi oleh Singapura dan Indonesia. Indonesia memiliki daya saing pada komoditas cengkeh pada tahun 2005-2007, pala, lawang dan kapulaga pada seluruh periode pengamatan. Pada periode 2005-2007 hanya Indonesia yang memiliki daya saing rempah untuk cengkeh dan pala, lawang serta kapulaga. Sedangkan pada tahun 2008-2013, Indonesia masih memiliki daya saing pada pala, lawang, dan kapulaga. Sehingga secara umum penelitian tersebut menyimpulkan bahwa daya saing ekspor rempah Indonesia mengalami peningkatan, yaitu bergeser dari kategori pengembangan ke kategori potensial.

Pada tahun 1917 David Ricardo mengeemukakan istilah comparative advantage (keunggulan komparatif) mulamula dikemukakan oleh sewaktu membahas perdagangan antar dua negara. Metode RCA pertama kali diperkenalkan dan ditemukan oleh Ballasa pada tahun 1965, ia menganggap bahwa keunggulan komparatif suatu negara direfleksikan oleh ekspornya. Suatu negara memiliki keunggulan komparatif dalam 
memproduksi suatu barang bila biaya pengorbanannya dalam memproduksi barang tersebut lebih rendah daripada negara-negara lainnya (Krugman dan Obstfeld 2003).

Menurut Basri dan Munandar (2010), metode RCA digunakan untuk mengukur kinerja ekspor komoditas tertentu dari suatu negara dengan mengevaluasi peranan ekspor komoditas tersebut di dalam ekspor total suatu negara dibandingkan dengan pangsa komoditas tersebut dalam perdagangan dunia. Konsep dari metode RCA adalah bahwa perdagangan antar wilayah sebenarnya menunjukkan keunggulan komparatif yang dimiliki oleh suatu wilayah. Variabel yang diukur adalah kinerja ekspor suatu produk terhadap total ekspor suatu wilayah yang kemudian dibandingkan dengan pangsa nilai produk dalam perdagangan dunia (Tarman et al 2011). Melalui pengukuran dengan metode RCA ini, akan diketahui keunggulan komperatif suatu negara. Keunggulan komparatif tersebut merupakan daya saing suatu komoditas ekspor dari suatu negara terhadap ekspor komoditas tersebut di seluruh dunia.

Selain RCA, dikenal pula metode lain yang digunakan untuk mengukur daya saing, yaitu Export product dynamic (EPD). Metode ini digunakan untuk menentukan keunggulan kompetitif komoditas tertentu dari suatu negara. EPD juga dapat menentukan gerakan dinamis suatu komoditas, yaitu apakah daya saing suatu produk mempunyai performa yang dinamis (memiliki pertumbuhan cepat) atau tidak, dengan kata lain melihat posisi daya saing produk terhadap negara importir terbesar.. Jika pertumbuhan komoditas itu berada di atas rata-rata dunia dan keadaan ini berlanjut dalam jangka panjang, komoditas ini akhirnya dapat menjadi sumber penting pendapatan ekspor suatu negara.
Menurut Esterhuizen (2006), keberhasilan di pasar ekspor perlu diinterpretasikan dengan hati-hati. Misalnya hilangnya beberapa pangsa pasar dalam perdagangan tidak selalu berarti hilangnya daya saing secara keseluruhan, yaitu apabila ada peningkatan pangsa pada produk lain. Produk dari perusahaan dan industri suatu negara dianggap kompetitif apabila pangsa pasar mereka terus meningkat, dan dianggap dinamis dalam perdagangan dunia jika pangsa pasarnya tumbuh lebih cepat daripada rata-rata pertumbuhan semua produk. Dalam metode Export Product Dynamic, posisi pasar yang ideal adalah memiliki pangsa ekspor yang tinggi sebagai rising stars yang mengindikasikan bahwa produk negara tersebut memiliki pangsa pasar yang tumbuh cepat. Sedangkan posisi lost opportunity, merupakan posisi hilangnya pangsa pasar dari produk yang sebetulnya dinamis. Posisi ini merupakan posisi yang paling tidak diinginkan. Falling stars juga merupakan posisi yang tidak diinginkan, sebab dalam posisi ini berada dalam kondisi dimana pangsa pasar meningkat, namun produk tidak dinamis. Posisi ini lebih baik bila dibandingkan dengan posisi lost opportunity. Sedangkan posisi retreat merupakan posisi yang juga tiak diinginkan,yaitu dimana pangsa pasar hilang dan produk tidak dinamis.

\section{Faktor-faktor yang Mempengaruhi Permintaan Ekspor}

Dalam aktifitas perdagangan internasional, ada berbagai macam faktor yang dapat mempengaruhi ekspor. Menurut Tambunan (2001) perdagangan internasional dipengaruhi oleh faktorfaktor yang dapat dilihat dari teori penawaran atau permintaan. Dalam penelitian ini variabel yang digunakan untuk menentukan faktor-faktor yang mempengaruhi ekspor komoditas pala, 
lawang dan kapulaga adalah variabel PDB per kapita negara tujuan, populasi negara tujuan, harga ekspor, dan jarak ekonomi antara negara asal dengan negara tujuan, dan tarif negara tujuan.

PDB per kapita dapat didefinisikan sebagai perbandingan antara PDB dengan jumlah populasi. Menurut Mankiw (2006), PDB per kapita suatu negara diperoleh dari PDB negara tersebut dibagi dengan jumlah populasinya. Variabel PDB per kapita dalam penelitian ini mencerminkan kemampuan daya beli dari masyarakat suatu negara terhadap komoditas yang diteliti. Menurut Elshehawy et al (2014), PDB negara tujuan merupakan salah satu faktor yang mempengaruhi permintaan ekspor negara. Sedangkan dalam penelitian yang berjudul Analisis Pengaruh dan Tingkat Keberhasilan Perdagangan Indonesia dalam ASEANIndia Free Trade Agrrement (AIFTA) ditemukan bahwa PDB per kapita memiliki pengaruh yang positif dan signifikan terhadap ekspor (Andari 2017).

Populasi suatu negara merupakan salah satu faktor yang mempengaruhi permintaan suatu produk. Pada dasarnya jumlah populasi suatu negara menunjukkan besarnya potensi pasar suatu negara. Negara dengan populasi yang besar diidentikan sebagai pasar yang potensial untuk menjual suatu produk. Semakin besar jumlah populasi, maka semakin besar pula potensinya. Menurut Yuniarti (2007) dalam penelitiannya yang berjudul Analisis Determinan Perdagangan Bilateral Indonesia Pendekatan Gravity Model, populasi mitra dagang memiliki pengaruh yang positif terhadap perdagangan bilateral. Menurut Telaumbanua (2011) dalam penelitian menemukan bahwa semakin besar populasi suatu negara maka semakin tinggi pula kemampuan negara tersebut dalam melakukan perdagangan dengan negara lain, khususnya kemampuan negara tersebut dalam membiayai impornya. Hal ini berarti bahwa semakin besar populasi di negara tujuan ekspor, maka akan semakin besar ekspor dari negara negara asal ke negara tujuan.

Dalam hukum permintaan, harga adalah salah satu faktor yang mempengaruhi permintaan. Apabila harga meningkat, maka permintaan barang akan menurun. Sebaliknya bila harga barang turun, maka tingkat permintaan barang akan meningkat. Hukum permintaan ini pun berlaku pula dalam kegiatan ekspor dan impor. Berdasarkan teori Batiz dan Batiz (1994) permintaan ekspor terutama dipengaruhi oleh harga riil dan pendapatan riil negara tujuan Menurut penelitian yang dilakukan oleh Tarman et al (2011), harga merupakan salah satu faktor yang mempengaruhi permintaan ekspor. Hubungan antara harga barang dengan ekspor adalah hubungan negatif. Hal ini terjadi karena saat harga naik, konsumen berusaha untuk mengurangi jumlah konsumsinya (Lipsey 1995).

Jarak adalah indikator dari biaya transportasi dalam melakukan perdagangan. Biaya transportasi adalah salah satu faktor penghambat perdagangan internasional. Jarak dapat meningkatkan biaya transaksi pertukaran barang dan jasa internasional. Jauh dekatnya jarak antara dua negara merupakan salah satu faktor yang dapat mempengaruhi aktifitas perdagangan internasional. Jarak yang ada antara kedua negara dapat menentukan mudah atau sulitnya barang melintasi ruang. Selain itu jarak juga mempengaruhi waktu dan biaya perdagangan. Menurut Inayah et al (2015) jarak ekonomi menunjukkan biaya transportasi yang dikenakan kepada pengimpor, juga menunjukkan biaya komunikasi dan waktu pengiriman ke negara pengimpor.

Tarif merupakan bea masuk, cukai atau pajak yang dikenakan oleh negara tujuan ekspor terhadap barang yang diperdagangkan antar negara. Tarif adalah bentuk kebijakan perdagangan yang 
digunakan pemerintah sebagai penerimaan negara. Berdasarkan penelitian yang dilakukan oleh Kis-Katos dan Sparrow (2015), keberadaan tarif memberikan hubungan yang berpengaruh negatif terhadap ekspor. Sehingga apabila tarif naik maka nilai ekspor akan turun, sebaliknya bila tarif mengalami penurunanan atau penghapusan maka nilai ekspor akan meningkat.

\section{Penelitian Terdahulu}

Dalam penelitian Hermawan (2015) tentang daya saing rempah Indonesia di pasar ASEAN periode pra dan pasca krisis ekonomi global, penelitian tersebut menggunakan metode Revealed Comparative Advantage (RCA), IntraIndustry Trade (IIT), Index of Export Overlap (IEO), dan Index of Export Similarity (IES) untuk mengukur daya saing rempah. Berdasarkan hasil perhitungan RCA, daya saing pasar rempah di ASEAN-5 didominasi oleh Singapura dan Indonesia. Indonesia memiliki daya saing pada komoditas cengkeh pada tahun 2005-2007, pala, lawang dan kapulaga pada seluruh periode pengamatan. Pada periode 2005-2007 hanya Indonesia yang memiliki daya saing rempah untuk cengkeh dan pala, lawang serta kapulaga. Sedangkan pada tahun 2008-2013, Indonesia masih memiliki daya saing pada pala, lawang, dan kapulaga. Sehingga secara umum penelitian tersebut menyimpulkan bahwa daya saing ekspor rempah Indonesia mengalami peningkatan, yaitu bergeser dari kategori pengembangan ke kategori potensial.

Dalam penelitian Permatasari dan Rustariyuni (2015) yang berjudul Analisis Daya Saing Ekspor Biji Kakao Indonesia di Kawasan ASEAN Periode 2003-2012, penelitian tersebut juga menggunakan metode Revealed Comparative Advantage (RCA) untuk mengukur daya saing Biji
Kakao. Selain RCA, penelitian tersebut juga menggunakan metode Constant Market Share Analysis (CMSA). Sedangkan dalam penelitian Hasibuan et al (2012) yang berjudul Analisis Kinerja dan Daya Saing Perdagangan Biji Kakao dan Produk Kakao Olahan Indonesia di Pasar Internasional, penelitian tersebut menggunakan metode Revealed Comparative Advantage (RCA), Indeks Spesialisasi Perdagangan (ISP), Export Product Dynamic (EPD) dan Constant Market Share Analysis (CMSA). Berdasarkan penelitian tersebut, ditemukan bahwa Indonesia mengalami surplus dalam perdagangan kakao. Indonesia juga memiliki keunggulan komparatif sebagai eksportir biji kakao dan kakao olahan di pasar internasional. Hasil analisis EPD hampir semua produk kakao memiliki daya saing, sedangkan analisis CMSA menunjukkan produkproduk kakao yang memiliki daya saing adalah produk-produk kakao olahan.

Menurut Inayah et al (2015) dalam penelitiannya yang berjudul The Analysis of Export Determinant of Indonesian Pepper in the International Market, ditemukan bahwa Faktor-faktor yang signifikan memengaruhi permintaan ekspor lada Indonesia adalah PDB percapita negara tujuan, jarak ekonomi, harga ekspor, nilai tukar riil, dan partisipasi dalam FTA.

Dalam penelitian Tarman et al (2011) yang berjudul Kajian Kebijakan Pengembangan Pengembangan Pasar dan Produk Ekspor, metode yang digunakan adalah metode Trade Performance Index (TPI), Constant Market Share Analysis (CMSA), Export Product Dynamic (EPD), dan Gravity Model. Penelitian tersebut menemukan bahwa faktor-faktor yang memengaruhi nilai ekspor adalah volume ekspor negara asal ke negara tujuan, nilai tukar negara tujuan, PDB negara tujuan, dan jarak ekonomi antara negara asal dan negara tujuan. Penelitian tersebut 
menunjukkan bahwa volume ekspor negara asal dan PDB negara tujuan berpengaruh positif terhadap nilai ekspor. Sedangkan variabel nilai tukar negara tujuan dan jarak ekonomi antara kedua negara berpengaruh negatif terhadap nilai ekspor.

\section{METODE}

\section{Jenis dan Sumber Data}

Penelitian tentang cengkeh ini akan memberikan kontribusi dengan melengkapi hasil penelitian yang sudah ada. Kebaruannya ada pada kebaruan data terkini, serta ragam pasar yang diteliti yang merupakan sepuluh pasar terbesar Indonesia.

Data yang digunakan dalam penelitian ini adalah data sekunder yang bersifat kuantitatif. Jenis data yang digunakan adalah data panel yang terdiri dari data time series dan data cross section. Data time series yang digunakan adalah data tahunan selama lima belas tahun (2002-2016). Sedangkan data cross section yang digunakan adalah data sepuluh negara tujuan ekspor utama.

Data pendukung yang digunakan dalam penelitian ini bersumber dari Bank Indonesia, Badan Pusat Statistik (BPS), Kementerian Perdangan dan Kementerian Pertanian. Adapun data utama yang digunakan bersumber dari United Nations of Comodity Trade Database (UNComtrade), World Development Indicators (WDI) World Bank, World Trade Organization (WTO) dan Cepii. Kode HS dari komoditas cengkeh yang diteliti adalah kode HS 0907.

\section{Metode Analisis dan Pengolahan Data}

Metode analisis yang digunakan dalam penelitian ini disesuaikan dengan tujuan penelitian, yaitu metode RCA, EPD, X-Model, dan gravity model.

\section{Revalead Comparative Advantage (RCA) \\ Revalead Comparative Advantage} (RCA) merupakan salah satu metode yang digunakan untuk mengukur daya saing atau keunggulan komparatif di suatu wilayah, baik negara, provinsi, dan lainlain. Variabel yang digunakan adalah kinerja ekspor suatu komoditas terhadap total ekspor di wilayah yang kemudian dibandingkan dengan pangsa nilai produk di dalam perdagangan dunia internasional. Adapun rumus dari RCA adalah sebagai berikut:

$$
R C A=\frac{\left(X_{a j}\right) /\left(X_{t j}\right)}{\left(W_{a j}\right) /\left(W_{t j}\right)}
$$

dimana :

$\mathrm{X}_{\mathrm{aj}}$ : Nilai ekspor cengkeh Indonesia ke negara $\mathrm{j}$

$\mathrm{W}_{\mathrm{aj}}$ : Nilai ekspor cengkeh dunia ke negara $\mathrm{j}$

$\mathrm{X}_{\mathrm{tj}}$ : Nilai total ekspor Indonesia ke negara $\mathrm{j}$

$\mathrm{W}_{\mathrm{tj}}$ : Nilai total ekspor dunia ke negara $\mathrm{j}$

Hasil perhitungan nilai RCA menunjukkan dua kemungkinan, yaitu bila nilai RCA lebih dari satu (RCA > 1) maka negara tersebut memiliki keunggulan komparatif di atas rata-rata dunia sehingga komoditas tersebut memiliki nilai daya saing yang kuat. Apabila nilai RCA kurang dari satu (RCA < 1) maka keunggulan komparatif negara tersebut di bawah rata-rata dunia sehingga komoditas tersebut dianggap memiliki daya saing yang lemah. Sehingga dapat disimpulkan bahwa semakin besar nilai RCA suatu komoditas wilayah tertentu, semakin besar pula daya saingnya. Dan semakin rendah nilai RCA suatu komoditas di wilayah tertentu, semakin rendah pula daya saingnya.

\section{Export Product Dynamics (EPD)}

Hasil perhitungan EPD merupakan matriks yang terdiri dari pertumbuhan pangsa pasar ekspor dan pertumbuhan 
pangsa pasar produk. EPD menghasilkan empat kategori posisi karakter, yaitu Rising Star, Falling Star, Lost Opportunity, dan Retreat. (Estherhuizen, 2006).

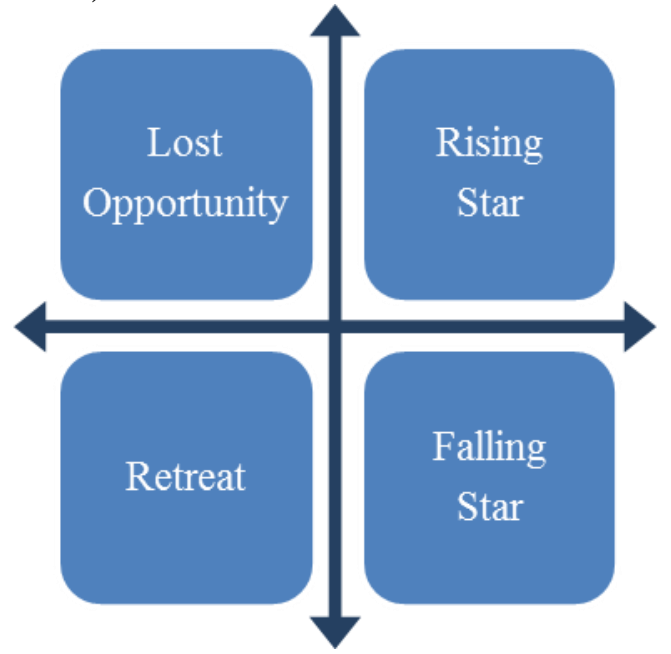

Gambar 1 Posisi Daya Saing Produk dengan Metode EPD

Sumber : Estherhuizen, 2006

Sumbu x: Pertumbuhan pangsa pasar ekspor

$\sum_{t=1}^{t}\left(\left(\frac{X_{a j}}{W_{a j}}\right)_{t} \times 100 \%-\left(\frac{X_{a j}}{W_{a j}}\right)_{t-1} \times 100 \%\right)$
Sumbu y: Pertumbuhan pangsa pasar produk

$\frac{\sum_{t=1}^{t}\left(\left(\frac{X_{t j}}{W_{t j}}\right)_{t} \times 100 \%-\left(\frac{X_{t j}}{W_{t j}}\right)_{t-1} \times 100 \%\right)}{T}$

Dimana:

$\mathrm{X}_{\mathrm{aj}}$ : Nilai ekspor komoditas a Indonesia ke negara $\mathrm{j}$

$\mathrm{W}_{\mathrm{aj}}$ : Nilai ekspor komoditas a dunia ke negara $\mathrm{j}$

$\mathrm{X}_{\mathrm{tj}}$ : Nilai total ekspor Indonesia ke negara $\mathrm{j}$

$\mathrm{W}_{\mathrm{tj}}$ : Nilai total ekspor dunia ke negara $\mathrm{j}$

$\mathrm{T}$ : Jumlah tahun

\section{X-Model Potential Export Products}

$X$-Model Potential Export Products merupakan metode yang menggabungkan antara metode Revalead Comparative Advantage (RCA) dan metode Export Product Dynamics (EPD). Metode ini digunakan untuk melakukan klusterisasi potensi pengembangan produk di wilayah tertentu. Klusterisasi ini dilakukan untuk memfokuskan pasar perdagangan.

$$
\text { T }
$$

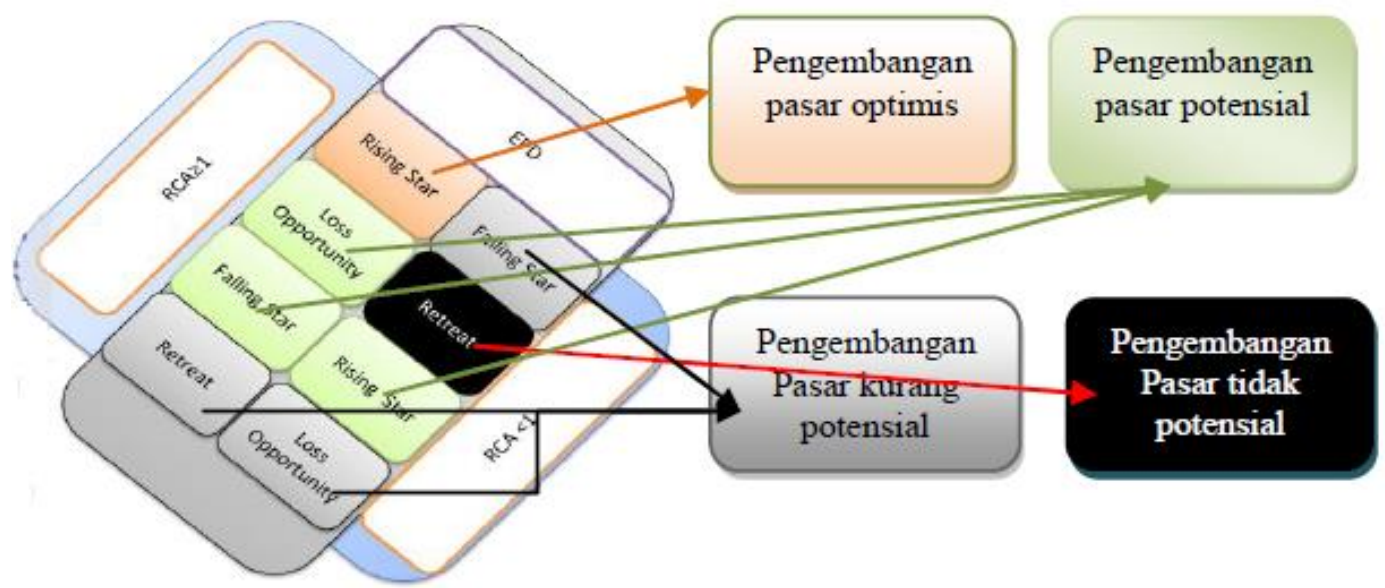

Gambar 2. Analisis X-Model Potential Export Products

\section{Gravity Model}

Analisis faktor yang mempengaruhi ekspor dilakukan dengan metode gravity model. Metode ini pertama kali digunakan dalam analisis perdagangan internasional oleh Jan Tinberger pada tahun 1962 untuk menganalisis aliran perdagangan antara negara-negara Eropa (Head 2003). 
Gravity Model mengadaptasi hukum gravitasi dari Newton, dimana atraksi atau gaya tarik gravitasi dari dua objek adalah proporsional dari massa mereka dan berbanding terbalik terhadap jarak mereka (Yuniarti 2007). Metode ini digunakan untuk menganalisis faktor-faktor yang mempengaruhi ekspor cengkeh ke pasar ekspor utama (Elshehawy et al 2014; KisKatos \& Sparrows 2015).

$$
\begin{gathered}
\ln X_{i j t}=\beta_{0}+\beta_{1} \ln P D B C_{j t}+\beta_{2} \ln P O P_{j t}+ \\
\beta_{3} \ln H E_{i j t}+\beta_{4} \ln J E_{i j t}+\beta_{5} T_{R F} F_{j t}+u_{i j t}
\end{gathered}
$$

dimana :

$\mathrm{X}_{\mathrm{ijt}} \quad$ : Volume ekspor pala, lawang dan kapulaga dari negara Indonesia ke negara j tahun ke-t $(\mathrm{kg})$

$\mathrm{PDBC}_{\mathrm{jt}}$ : Produk Domestik Bruto per kapita negara $\mathrm{j}$ tahun ke-t (US\$/Jiwa)

$\mathrm{POP}_{\mathrm{jt}} \quad$ : Populasi negara $\mathrm{j}$ tahun ke- $\mathrm{t}$ (Jiwa)

$\mathrm{HE}_{\mathrm{ijt}} \quad$ : Harga ekspor pala, lawang dan kapulaga Indonesia ke negara $\mathrm{j}$ tahun ke-t (US\$/Kg)

$\mathrm{JE}_{\mathrm{ijt}} \quad$ : Jarak ekonomi antara kedua negara $(\mathrm{Km})$

$\mathrm{TRF}_{\mathrm{jt}} \quad$ : Tarif impor negara $\mathrm{j}$ tahun ke-t (Persen)

In : Logaritma natural

$\beta_{0} \quad$ : Intersep

$\beta_{\mathrm{n}} \quad$ : Slope

$\mathrm{u}_{\mathrm{ijt}} \quad$ : error term

Adapun nilai dari jarak ekonomi yang digunakan didapat dari rumus yang mengacu pada penelitian Inayah et al (2015).

$$
\mathrm{JE}_{\mathrm{ij}}=\mathrm{DIS}_{\mathrm{ij}} \times \frac{\mathrm{PDB}_{\bar{j}}}{\sum \mathrm{PDB}_{\tilde{j}}}
$$

dimana :

$\mathrm{JE}_{\mathrm{ij}} \quad$ : Jarak ekonomi antara negara Indonesia dengan negara $\mathrm{j}(\mathrm{km})$

DIS $_{\mathrm{ij}} \quad$ : Jarak ibu kota negara Indonesia dengan ibu kota negara $\mathrm{j}(\mathrm{km})$
$\mathrm{PDB}_{\mathrm{j}} \quad$ : Produk Domestik Bruto negara $\mathrm{j}$ (USD)

$\sum \mathrm{PDB}_{\mathrm{j}}$ : Total Produk Domestik Bruto seluruh negara $\mathrm{j}$ (USD)

\section{HASIL DAN PEMBAHASAN Gambaran Umum}

Cengkeh merupakan tanaman cengkeh yang berasal dari keluarga pohon Myrtaceae. Hasil utama tanaman cengkeh adalah bunganya. Bunga tersebut dipanen sebelum mekar dan kemudian dikeringkan. Cengkeh dalam keadaan segar biasanya berwarna hijau atau merah dan berwarna coklat kehitaman apabila dikeringkan. Bentuk cengkeh seperti bunga kecil, beraroma wangi dan agak pedas. Tanaman cengkeh merupakan salah satu tanaman yang tumbuh di wilayah yang beriklim tropis. Tanaman ini dapat tumbuh pada ketinggian 0-900 meter di atas permukaan air laut. Sentra produksi komoditas cengkeh Indonesia berada di delapan provinsi, yaitu Sulawesi Selatan, Maluku, Sulawesi Utara, Jawa Timur, Sulawesi Tengah, Jawa Tengah, Sulawesi Tenggara dan Jawa Barat. Secara kumulatif produksi cengkeh di delapan provinsi tersebut berkontribusi sebesar 77,31 persen dari total produksi cengkeh Indonesia (Kementan, 2014).

Di Indonesia, komoditas cengkeh sebagian besar digunakan sebagai bahan utama rokok kretek khas Indonesia. Sedangkan di negara-negara Eropa dan Amerika, cengkeh banyak digunakan sebagai bumbu masakan pedas. Selain sebagai bahan masakan, ekspor cengkeh juga digunakan untuk industri farmasi dan kosmetik di negara tujuan. Cengkeh mengandung hingga 85 persen Eugenol. Eugenol ini biasanya digunakan untuk memproduksi parfum, sabun, dan anestesi gigi.

Di pasar dunia, pada tahun 2016 Indonesia menjadi eksportir cengkeh 
kedua terbesar. Kontribusi ekspor Indonesia di pasar dunia adalah sebesar $12.754 .369 \mathrm{~kg}$ atau setara dengan 22,78 persen dari total ekspor dunia. Kompetitor terbesar ekspor cengkeh Indonesia adalah negara Madagaskar yang merupakan eksportir terbesar di pasar dunia. Ekspor Madagaskar ke pasar dunia pada tahun 2016 sebanyak $20.895 .621 \mathrm{~kg}$ atau setara dengan 37,3 persen dari ekspor cengkeh dalam perdagangan internasional. Selain Madagaskar, kompetitor lainnya adalah Singapura, India, Brazil, Uni Emirat Arab, Vietnam, Saudi Arabia, Amerika Serikat dan Pakistan.

Selama tahun 2002 hingga 2016 Indonesia telah mengekspor cengkeh secara kontinyu ke 21 negara. Dari 21 negara tersebut, sepuluh pasar utama yang paling mendominasi ekspor cengkeh Indonesia adalah pasar Saudi Arabia, Vietnam, Malaysia, Pakistan, Uni Emirat Arab, Belanda, Thailand, Jerman, Mesir dan Australia. Selama lima belas tahun tersebut volume ekspor cengkeh Indonesia di pasar tersebut berfluktuasi, namun demikian rata-rata ekspornya bertumbuh.

Dari seluruh pasar ekspor utama komoditas cengkeh Indonesia, pasar yang paling mendominasi volume ekspor komoditas ini adalah pasar Vietnam. Total volume ekspor cengkeh ke pasar Vietnam selama tahun 2002 hingga tahun 2016 adalah 18.206 ton. Sedangkan di pasar Saudi Arabia total volume ekspor cengkeh Indonesia adalah sebanyak 9.170 ton, selanjutnya di pasar Pakistan sebanyak 5.104 ton, di pasar Uni Emirat Arab 4.201 ton, di pasar Malaysia 3.920 ton, di pasar Mesir sebanyak 37702 ton, di pasar Belanda 3.532 ton, di pasar Jerman 917 ton, di pasar Thailand sebanyak 775 ton, dan total volume ekspor terendah adalah total volume ekspor ke pasar Australia senilai 635 ton.

Tabel 1 Volume ekspor cengkeh Indonesia ke sepuluh pasar utama (dalam ton)

\begin{tabular}{|c|c|c|c|c|c|c|c|c|c|c|}
\hline Tahun & Malaysia & UEA & Vietnam & Pakistan & Saudi.A & Thailand & Australia & Belanda & Mesir & Jerman \\
\hline 2002 & 589 & 336 & 334 & 178 & 211 & 75 & 18 & 472 & 22 & 78 \\
\hline 2003 & 259 & 592 & 1.751 & 520 & 1.900 & 20 & 14 & 125 & 12 & 69 \\
\hline 2004 & 132 & 339 & 216 & 178 & 390 & 14 & 32 & 169 & 2 & 57 \\
\hline 2005 & 137 & 284 & 1.103 & 181 & 724 & 34 & 48 & 95 & 83 & 20 \\
\hline 2006 & 436 & 416 & 521 & 275 & 759 & 31 & 56 & 92 & 235 & 8 \\
\hline 2007 & 448 & 505 & 997 & 487 & 1.560 & 46 & 94 & 133 & 253 & 25 \\
\hline 2008 & 305 & 398 & 304 & 77 & 561 & 44 & 35 & 81 & 268 & 16 \\
\hline 2009 & 156 & 190 & 567 & 219 & 414 & 46 & 44 & 143 & 59 & 0.4 \\
\hline 2010 & 138 & 301 & 876 & 162 & 650 & 39 & 51 & 166 & 436 & 40 \\
\hline 2011 & 134 & 34 & 778 & 163 & 197 & 23 & 15 & 187 & 304 & 5 \\
\hline 2012 & 297 & 75 & 1.245 & 193 & 453 & 37 & 17 & 455 & 142 & 45 \\
\hline 2013 & 227 & 12 & 1.168 & 237 & 396 & 163 & 5 & 480 & 314 & 59 \\
\hline 2014 & 244 & 69 & 1.287 & 510 & 466 & 56 & 50 & 679 & 487 & 89 \\
\hline 2015 & 250 & 316 & 3.224 & 957 & 720 & 75 & 75 & 170 & 691 & 275 \\
\hline 2016 & 165 & 335 & 3.834 & 765 & 1.327 & 71 & 80 & 84 & 395 & 131 \\
\hline $\begin{array}{l}\text { Rata-rata } \\
\text { Pertumbuhan } \\
\text { (persen) }\end{array}$ & 7,05 & 60,69 & 77,19 & 39,69 & 77,78 & 26,85 & 69,43 & 6,43 & 313,48 & 726,24 \\
\hline
\end{tabular}


Besarnya volume ekspor cengkeh di setiap pasar tujuan utama pada setiap tahunnya berfluktuasi. Adakalanya mengalami peningkatan namun adakalanya pula mengalami penurunan. Namun demikian, secara rata-rata pertumbuhan volume ekspor cengkeh Indonesia tahun 2002 hingga tahun 2016 bernilai positif. Rata-rata pertumbuhan volume ekspor terbesar adalah di pasar Jerman, yaitu dengan besar rata-rata pertumbuhan sebesar 726,23 persen per tahun. Sedangkan pertumbuhan volume ekspor terendah adalah pertumbuhan di pasar Belanda dengan pertumbuhan sebesar 6,43 persen per tahun.

Pada data nilai ekspor komoditas cengkeh Indonesia di pasar tujuan utama, pasar yang paling mendominasi nilai ekspor komoditas ini adalah pasar Saudi Arabia. Total nilai ekspor cengkeh ke pasar Saudi Arabia selama tahun 2002 hingga tahun 2016 adalah 43.803.591 USD. Sedangkan total nilai ekspor cengkeh di pasar lain secara berurutan adalah di pasar Vietnam sebesar 27.368.239 USD, di pasar Malaysia sebesar 13.541.347 USD, di pasar Pakistan sebesar 13.234.951 USD, di pasar Uni Emirat Arab senilai 8.277.715 USD, di pasar Belanda sebanyak 5.928.082 USD, ekspor di pasar Thailand sebanyak 3.486.720 USD, di pasar Jerman 3.449.360 USD, di pasar Mesir sebanyak 3.225.565 USD dan total nilai ekspor terendah adalah total nilai ekspor ke pasar Australia senilai 2.666.037 USD.

Tabel 2 Nilai Ekspor Cengkeh Indonesia ke Sepuluh Pasar Utama (dalam ribu USD)

\begin{tabular}{|c|c|c|c|c|c|c|c|c|c|c|}
\hline Tahun & Malaysia & UEA & Vietnam & Pakistan & Saudi.A & Thailand & Australia & Belanda & Mesir & Jerman \\
\hline 2002 & 1.623 & 929 & 872 & 475 & 552 & 161 & 16 & 449 & 35 & 256 \\
\hline 2003 & 257 & 562 & 2.977 & 891 & 3.136 & 43 & 28 & 238 & 19 & 87 \\
\hline 2004 & 317 & 454 & 239 & 381 & 1.007 & 23 & 65 & 225 & 2 & 23 \\
\hline 2005 & 248 & 433 & 1.072 & 377 & 2.120 & 87 & 174 & 93 & 39 & 5 \\
\hline 2006 & 657 & 673 & 307 & 477 & 2.372 & 110 & 142 & 158 & 105 & 2 \\
\hline 2007 & 1.128 & 827 & 1.017 & 1.569 & 4.019 & 160 & 301 & 280 & 137 & 4 \\
\hline 2008 & 1.281 & 143 & 97 & 41 & 1.248 & 164 & 166 & 72 & 88 & 6 \\
\hline 2009 & 644 & 134 & 551 & 135 & 1.031 & 161 & 158 & 148 & 30 & 2 \\
\hline 2010 & 477 & 164 & 3.281 & 455 & 2.615 & 215 & 154 & 129 & 197 & 55 \\
\hline 2011 & 428 & 16 & 2.376 & 455 & 1.303 & 209 & 43 & 235 & 149 & 6 \\
\hline 2012 & 1.776 & 86 & 2.667 & 440 & 2.878 & 383 & 200 & 928 & 190 & 327 \\
\hline 2013 & 1.168 & 14 & 2.284 & 818 & 3.462 & 417 & 76 & 691 & 559 & 217 \\
\hline 2014 & 1.472 & 317 & 1.169 & 1.243 & 5.111 & 429 & 290 & 1.612 & 554 & 476 \\
\hline 2015 & 1.180 & 1.524 & 2.871 & 2.546 & 5.010 & 433 & 381 & 587 & 648 & 1.261 \\
\hline 2016 & 882 & 2.002 & 5.589 & 2.930 & 7.938 & 491 & 470 & 82 & 472 & 719 \\
\hline $\begin{array}{l}\text { Rata-rata } \\
\text { Pertumbuhan } \\
\text { (persen) }\end{array}$ & 24,53 & 194,03 & 121,09 & 64,88 & 61,03 & 25,98 & 70,35 & 27,87 & 179,87 & 559,20 \\
\hline
\end{tabular}

Besarnya nilai ekspor cengkeh di setiap pasar tujuan utama pada setiap tahunnya berfluktuasi. Adakalanya mengalami peningkatan namun adakalanya pula mengalami penurunan. Namun demikian, secara rata-rata pertumbuhan volume ekspor cengkeh Indonesia tahun 2002 hingga tahun 2016 bernilai positif di setiap pasarnya. Secara keseluruhan rata-rata volume ekspor di 
setiap pasar bertumbuh. Pertumbuhan ekspor tertinggi adalah sebesar 559,20 persen di pasar Jerman, sedangkan ratarata pertumbuhan ekspor terendah adalah di pasar Malaysia sebesar 24,53 persen.

Berdasarkan data volume dan nilai ekspor cengkeh Indonesia ke sepuluh pasar utama tersebut, terlihat adanya perbedaan fluktuasi dan pertumbuhan pada volume ekspor dan nilai ekspor komoditas tersebut. Adanya perbedaan ini disebabkan oleh perubahan harga ekspor cengkeh dari tahun ke tahun di setiap negara. Perubahan harga ekspor cengkeh setiap tahunnya menyebabkan laju pertumbuhan volume ekspor lebih lambat dibanding dengan laju pertumbuhan nilai ekspornya.

Tabel 3 Harga Ekspor Cengkeh Indonesia

\begin{tabular}{ccccccccccc}
\hline Tahun & Malaysia & UEA & \multicolumn{2}{c}{ Vietnam Pakistan } & Saudi.A & Thailand & Australia & Belanda & Mesir & Jerman \\
\hline 2002 & 2,75 & 2,77 & 2,61 & 2,68 & 2,62 & 2,13 & 0,89 & 0,95 & 1,62 & 3,29 \\
2003 & 0,99 & 0,95 & 1,70 & 1,71 & 1,65 & 2,17 & 2,07 & 1,90 & 1,56 & 1,26 \\
2004 & 2,41 & 1,34 & 1,11 & 2,14 & 2,58 & 1,61 & 2,05 & 1,33 & 0,92 & 0,41 \\
2005 & 1,81 & 1,53 & 0,97 & 2,08 & 2,93 & 2,58 & 3,66 & 0,98 & 0,47 & 0,28 \\
2006 & 1,51 & 1,62 & 0,59 & 1,73 & 3,12 & 3,54 & 2,53 & 1,71 & 0,45 & 0,27 \\
2007 & 2,52 & 1,64 & 1,02 & 3,22 & 2,58 & 3,50 & 3,18 & 2,11 & 0,54 & 0,18 \\
2008 & 4,19 & 0,36 & 0,32 & 0,53 & 2,22 & 3,74 & 4,69 & 0,89 & 0,33 & 0,38 \\
2009 & 4,12 & 0,71 & 0,97 & 0,62 & 2,49 & 3,51 & 3,58 & 1,03 & 0,52 & 4,17 \\
2010 & 3,45 & 0,54 & 3,75 & 2,80 & 4,02 & 5,48 & 3,04 & 0,78 & 0,45 & 1,39 \\
2011 & 3,19 & 0,47 & 3,05 & 2,79 & 6,62 & 9,13 & 2,83 & 1,25 & 0,49 & 1,30 \\
2012 & 5,97 & 1,14 & 2,14 & 2,28 & 6,35 & 10,27 & 11,49 & 2,04 & 1,34 & 7,19 \\
2013 & 5,14 & 1,19 & 1,96 & 3,45 & 8,73 & 2,56 & 13,86 & 1,44 & 1,78 & 3,69 \\
2014 & 6,02 & 4,59 & 0,91 & 2,44 & 10,97 & 7,59 & 5,77 & 2,37 & 1,14 & 5,37 \\
2015 & 4,71 & 4,82 & 0,89 & 2,66 & 6,96 & 5,80 & 5,10 & 3,46 & 0,94 & 4,59 \\
2016 & 5,34 & 5,98 & 1,46 & 3,83 & 5,98 & 6,92 & 5,86 & 0,97 & 1,20 & 5,48 \\
\hline $\begin{array}{c}\text { Rata-rata } \\
\text { Pertumbuhan } \\
\text { (persen) }\end{array}$ & 16,21 & 31,49 & 23,27 & 28,47 & 11,07 & 23,25 & 34,11 & 14,92 & 8,25 & 92,08 \\
\hline
\end{tabular}

Harga komoditas cengkeh Indonesia di setiap pasar pada setiap tahunnya cukup bervariasi. Adakalanya mengalami kenaikan namun adakalanya pula mengalami penurunan. Tingginya fluktuasi harga cengkeh tersebut terjadi karena karakteristik budidaya cengkeh yang memiliki siklus produksi periodik (4 tahun). Siklus ini ditandai dengan panen besar, kecil, dan panen raya, di mana produksi yang tinggi pada satu tahun tertentu akan diikuti dengan penurunan produksi pada satu hingga dua tahun berikutnya (Hermawan, 2015).

Secara rata-rata keseluruhan, harga ekspor komoditas cengkeh di setiap pasar mengalami peningkatan. Berdasarkan rata-rata, harga ekspor cengkeh tahun 2002 hingga tahun 2016 cukup bervariasi dan memiliki rata-rata harga yang berbeda di setiap pasarnya. Rata-rata harga ekspor tertinggi adalah seharga 4,71 USD/kg di pasar Australia, 4,70 USD/kg di pasar Thailand, 4,65 USD/kg di pasar Saudi Arab, 3,61 USD/kg di pasar Malaysia, 2,62 USD/kg di pasar Jerman, 2,33 USD/kg di pasar Pakistan, 1,97 USD/kg di pasar Uni Emirat Arab, 1,56 USD/kg di pasar vietnam, 1,55 USD/kg di pasar Belanda, dan rata-rata harga terendah adalah sebesar 0,92 USD/kg di pasar Mesir. 


\section{Daya Saing Cengkeh}

Berdasarkan hasil analisis dengan menggunakan metode RCA, selama periode 2002 sampai periode 2016, daya saing komoditas cengkeh Indonesia di setiap pasar memiliki nilai RCA yang cukup bervariasi. Komoditas cengkeh memiliki nilai daya saing yang berbedabeda pada setiap tahun di setiap pasar. Namun secara keseluruhan komoditas cengkeh Indonesia di sepuluh pasar utama yang diteliti memiliki daya saing yang kuat.

Tabel 2 Nilai RCA Cengkeh Indonesia di Sepuluh Pasar Tujuan Utama

\begin{tabular}{ccccccccccc}
\hline \multirow{2}{*}{ Tahun } & \multicolumn{10}{c}{ Negara } \\
\cline { 2 - 10 } & Malaysia & UEA & Vietnam & Pakistan & Saudi.A & Thailand & Australia & Belanda & Mesir & Jerman \\
\hline 2002 & 15,05 & 4,75 & 0,88 & 4,76 & 17,59 & 32,33 & 1,34 & 19,26 & 17,31 & 33,36 \\
2003 & 4,55 & 10,98 & 4,14 & 13,00 & 60,69 & 15,02 & 4,15 & 12,71 & 4,70 & 19,06 \\
2004 & 0,97 & 9,82 & 0,37 & 3,70 & 32,36 & 11,93 & 13,93 & 10,80 & 0,54 & 6,20 \\
2005 & 1,53 & 6,78 & 1,70 & 10,66 & 51,22 & 27,81 & 37,35 & 3,03 & 6,08 & 0,96 \\
2006 & 6,64 & 9,94 & 3,40 & 8,11 & 44,06 & 36,58 & 20,53 & 10,43 & 7,15 & 0,50 \\
2007 & 9,61 & 10,65 & 6,73 & 12,47 & 59,74 & 27,62 & 52,29 & 14,64 & 11,30 & 0,54 \\
2008 & 14,07 & 1,91 & 1,91 & 0,42 & 21,70 & 28,69 & 18,90 & 2,60 & 6,94 & 1,00 \\
2009 & 2,40 & 2,21 & 1,96 & 2,49 & 14,94 & 20,63 & 16,02 & 5,31 & 2,08 & 0,22 \\
2010 & 2,68 & 2,66 & 12,18 & 6,72 & 29,36 & 25,92 & 16,34 & 3,85 & 11,72 & 6,59 \\
2011 & 0,68 & 0,20 & 9,26 & 7,99 & 19,12 & 20,00 & 2,61 & 2,53 & 6,63 & 0,58 \\
2012 & 2,95 & 2,90 & 6,80 & 8,23 & 11,50 & 22,76 & 6,86 & 9,59 & 8,18 & 19,40 \\
2013 & 5,69 & 0,12 & 10,60 & 10,40 & 21,24 & 20,26 & 3,69 & 6,99 & 21,09 & 11,76 \\
2014 & 0,63 & 0,95 & 3,36 & 8,67 & 19,36 & 22,86 & 8,45 & 17,15 & 11,22 & 26,58 \\
2015 & 5,72 & 9,07 & 7,54 & 16,48 & 24,55 & 18,09 & 17,76 & 9,71 & 11,73 & 54,07 \\
2016 & 2,08 & 19,13 & 12,87 & 14,20 & 54,12 & 22,77 & 22,59 & 1,71 & 14,56 & 44,21 \\
\hline $\begin{array}{c}\text { Rata- } \\
\text { rata }\end{array}$ & 5,02 & 6,14 & 5,58 & 8,55 & 32,10 & 23,55 & 16,19 & 8,69 & 9,41 & 15,00 \\
\hline & & & & & & & & & & \\
\hline
\end{tabular}

Hasil analisis rata-rata nilai RCA menunjukkan bahwa komoditas cengkeh memiliki keunggulan komparatif dan berdaya saing kuat di setiap pasar pada setiap tahun yang diteliti, kecuali di pasar vietnam pada tahun 2002. Posisi daya saing dengan nilai rata-rata RCA tertinggi berada di pasar Saudi Arabia dengan ratarata nilai RCA sebesar 32,10, kemudian diurutan kedua dan seterusnya disusul dengan pasar Thailand, selanjutnya Australia, Jerman, Mesir, Belanda, Pakistan, Uni Emirat Arab, Vietnam, dan Malaysia.
Setelah dilakukan analisis RCA, selanjutnya dilakukan analisis lainnya mengenai daya saing komoditas cengkeh Indonesia yang dilakukan dengan menggunakan metode EPD. Pada hasil analisis EPD menunjukkan bahwa posisi pasar komoditas lada di masing-masing pasar cukup bervariasi. Ada yang berada pada posisi rising star, lost opportunity, falling star maupun retreat. 
Tabel 3 Hasil Analisis EPD Cengkeh Indonesia Tahun 2002-2016

\begin{tabular}{lccc}
\hline \multicolumn{1}{c}{ Negara } & $\begin{array}{c}\text { Pertumbuhan Pangsa } \\
\text { Pasar Ekspor }(\%)\end{array}$ & $\begin{array}{c}\text { Pertumbuhan Pangsa } \\
\text { Pasar Produk }(\%)\end{array}$ & Posisi Pasar \\
\hline Malaysia & -1.935 & 0.121 & Lost Opportunity \\
UEA & 0.741 & -0.126 & Falling Star \\
Vietnam & 1.493 & -0.016 & Falling Star \\
Thailand & 1.635 & 0.069 & Rising Star \\
Pakistan & 3.852 & 0.123 & Rising Star \\
Saudi Arabia & 2.893 & -0.042 & Falling Star \\
Australia & 2.457 & -0.078 & Falling Star \\
Belanda & -1.328 & 0.003 & Lost Opportunity \\
Mesir & 1.857 & 0.024 & Rising Star \\
Jerman & 0.726 & -0.001 & Falling Star \\
\hline
\end{tabular}

Ekspor komoditas cengkeh Indonesia berada pada posisi rising star di pasar Thailand, Pakistan, dan Mesir. Sedangkan di pasar Malaysia dan Belanda ekspor cengkeh Indonesia berada pada posisi lost opportunity. Ini berarti bahwa cengkeh Indonesia kehilangan kesempatan untuk meningkatkan pangsa pasar ekspor di pasar tersebut. Sedangkan di pasar Uni Emirat Arab, Vietnam, Saudi Arabia, Australia dan Jerman, ekspor cengkeh Indonesia berada pada posisi falling star, yaitu posisi dimana cengkeh Indonesia kehilangan kesempatan untuk meningkatkan pangsa pasar produknya.

Pada tahun 2008 dan 2011 produksi cengkeh Indonesia mengalami penurunan. Penurunan tersebutlah yang menjadi salah satu penyebab hilangnya pangsa pasar ekspor cengkeh Indonesia di pasar Malaysia dan Belanda. Pada tahun 2008 produksi cengkeh Indonesia turun sebesar 12.27 persen dan pada tahun 2011 produksi cengkeh Indonesia turun sebesar 26.57 persen Sedangkan faktor lain yang juga mempengaruhi hilangnya pangsa pasar cengkeh Indonesia pada tahun tersebut juga di tahun-tahun lainnya adalah karena adanya peralihan impor cengkeh di negara tersebut ke importir lainnya.
Di pasar Malaysia, hilangnya pangsa pasar ekspor komoditas cengkeh disebabkan oleh nilai perbandingan ekspor cengkeh Indonesia dengan ekpor cengkeh dunia di pasar Malaysia pada tahun 2009, 2011, 2014 dan 2016 lebih kecil daripada nilai perbandingan ekspor cengkeh Indonesia dengan ekspor cengkeh dunia di pasar Malaysia pada tahun sebelumnya. Pada 2009 perubahan komposisi volume impor cengkeh Indonesia yang terjadi di pasar Malaysia adalah karena pada tahun tersebut impor cengkeh di pasar Malaysia banyak beralih ke Singapura. Pada tahun 2014 Malaysia meningkatkan impor cengkeh diantaranya dari Singapura dan madagaskar. Selain itu pada tahun tersebut Malaysia juga mengimpor cengkeh dari beberapa importir baru, diantaranya dari Uni Emirat Arab dan Australia. Pada tahun 2016 Malaysia lebih banyak meningkatkan impor dari Singapura, Madagaskar dan India.

Di pasar Belanda, hilangnya pangsa pasar ekspor komoditas cengkeh disebabkan oleh nilai perbandingan ekspor cengkeh Indonesia dengan ekspor cengkeh dunia di pasar Belanda pada tahun 2008, 2010, 2011, 2013, 2015 dan 2016 lebih kecil daripada nilai perbandingan ekspor cengkeh Indonesia dengan ekspor cengkeh dunia di pasar Belanda pada tahun 
sebelumnya. Pada 2010 perubahan komposisi volume impor cengkeh Indonesia yang terjadi di pasar Malaysia adalah karena pada tahun tersebut impor cengkeh di pasar Malaysia banyak beralih ke Comoro dan Madagaskar. Pada tahun 2013 Malaysia mengimpor cengkeh dari beberapa importir baru, yaitu dari Kroasia, Republik Dominika, Hungaria, Uni Emirat Arab, Tanzania dan Amerika Serikat. Pada tahun 2015 Malaysia lebih banyak meningkatkan impor dari Madagaskar. Dan pada tahun 2016 Belanda lebih banyak mengimpor dari Inggris dan Brazil.

Pada pasar Uni Emirat Arab, Vietnam, Saudi Arabia, Australia dan Jerman, pertumbuhan pangsa pasar produk bernilai negatif. Ini berarti bahwa nilai ekspor total Indonesia ke pasar tersebut bila dibandingkan dengan nilai ekspor total dunia ke pasar tersebut secara rata-rata dari tahun ke tahun cenderung mengalami penurunan. Hal ini menyebabkan Indonesia kehilangan kesempatan untuk meningkatkan pangsa pasar produknya.

Setelah didapat hasil analisis RCA dan EPD, selanjutnya dilakukan klusterisasi potensi pengembangan pasar dengan menggunakan metode $\mathrm{x}$-model potential export products. Analisis ini dilakukan dengan mempertimbangkan hasil analisis RCA dan EPD yang telah didapat. Tabel 28 menampilkan hasil analisis $\mathrm{x}$-model kayu manis Indonesia.

Tabel 4 Hasil Analisis X-Model Komoditas Cengkeh

\begin{tabular}{lccc}
\hline \multicolumn{1}{c}{ Negara } & RCA & EPD & $\begin{array}{c}\text { Potensi Pengembangan } \\
\text { Pasar }\end{array}$ \\
\hline Malaysia & 5,02 & Lost Opportunity & Potensial \\
UEA & 6,14 & Falling Star & Potensial \\
Vietnam & 5,58 & Falling Star & Potensial \\
Thailand & 8,55 & Rising Star & Optimis \\
Pakistan & 32,1 & Rising Star & Optimis \\
Saudi Arabia & 23,55 & Falling Star & Potensial \\
Australia & 16,19 & Falling Star & Potensial \\
Belanda & 8,69 & Lost Opportunity & Potensial \\
Mesir & 9,41 & Rising Star & Optimis \\
Jerman & 15,00 & Falling Star & Potensial \\
\hline
\end{tabular}

Berdasarkan hasil analisis x-model, ekspor komoditas cengkeh memiliki potensi pengembangan pasar optimis di pasar Thailand, Pakistan dan Mesir. Di pasar-pasar tersebut komoditas cengkeh Indonesia memiliki daya saing yang kuat sekaligus berada pada posisi rising star. Di pasar Malaysia, pasar Uni Emirat Arab, pasar Vietnam, pasar Saudi Arabia, pasar Australia, pasar Belanda, dan Pasar Jerman, komoditas ini memiliki potensi pengembangan pasar yang potensial, sebab meskipun berada pada posisi lost opportunity atau falling star komoditas cengkeh memiliki daya saing kuat di negara tersebut.

\section{Analisis Faktor-faktor yang Memengaruhi Permintaan Cengkeh Indonesia}

Dalam menentukan model yang terbaik, maka dilakukan uji Chow dan uji Hausman. Berdasarkan hasil uji Chow (Lampiran 7) menunjukkan probabilitas 
lebih kecil dari taraf nyata lima persen $(0,00<0,05)$, berarti cukup bukti untuk tolak H0, artinya pendekatan model yang dipilih adalah pendekatan model fixed effect. Selanjutnya dilakukan uji Hausman. Hasil uji Hausman (Lampiran 8) menunjukkan bahwa nilai probabilitasnya lebih kecil dari taraf nyata lima persen $(0,00<0,05)$, berarti cukup bukti untuk tolak $\mathrm{H} 0$, artinya pendekatan model yang dipilih adalah pendekatan model fixed effect. Berdasarkan hasil pengujian, maka pendekatan model terbaik yang dipilih adalah pendekatan model fixed effect.

Pengolahan dengan pendekatan model fixed effect ini juga dilakukan dengan pilihan kriteria pembobotan, yaitu dengan memberikan pembobotan SUR cross-section weighted. Metode ini merupakan metode yang mampu mengoreksi heteroskedastisitas serta autokorelasi antar unit cross section, sehingga model yang dihasilkan dalam penelitian ini pun telah bebas dari heteroskedastisitas dan autokorelasi.

Berdasarkan hasil estimasi yang ditampilkan, nilai koefisien determinasi $\left(\mathrm{R}^{2}\right)$ untuk komoditas HS 0907 adalah sebesar 0,850407. Berarti bahwa keragaman faktor-faktor yang memengaruhi nilai ekspor komoditas HS 0907 dapat dijelaskan oleh variabelvariabel bebasnya sebesar $85.04 \%$, sedangkan $14,96 \%$ lainnya dijelaskan oleh faktor-faktor di luar model.

Tabel 5 Hasil estimasi faktor yang memengaruhi ekspor cengkeh Indonesia

\begin{tabular}{ccc}
\hline Variabel & Koefisien & Probability \\
\hline C & $-16,00202$ & 0,2326 \\
LNPDBC & 3,408406 & $0,0000^{*}$ \\
LNPOP & 0,681443 & 0,3138 \\
LNHE & $-0,081566$ & 0,2005 \\
LNJE & $-2,646193$ & $0,0185^{* *}$ \\
TRF & $-0,042667$ & $0,0065^{*}$ \\
\hline R-squared & \multicolumn{2}{c}{0,850407} \\
Adjusted R-squared & \multicolumn{2}{c}{0,834894} \\
\hline
\end{tabular}

Keterangan : *** Signifikan pada taraf nyata $1 \%, 5 \%$

Faktor-faktor yang signifikan memengaruhi permintaan ekspor cengkeh Indonesia adalah produk domestik bruto per kapita, jarak ekonomi dan tarif. Produk domestik bruto per kapita dan tarif memiliki pengaruh yang signifikan pada taraf nyata satu persen, variabel jarak ekonomi memiliki pengaruh yang signifikan pada tara nyata lima persen, sedangkan variable populasi dan harga ekspor tidak memiliki pengaruh nyata pada ekspor komoditas cengkeh Indonesia.

Variabel produk domestik bruto per kapita negara tujuan berpengaruh positif terhadap ekspor cengkeh Indonesia, dimana setiap kenaikan PDB per kapita negara tujuan sebesar satu persen maka volume ekspor kayu manis akan meningkat sebesar 3,41 persen, begitu pula sebaliknya (ceteris paribus). PDB per kapita negara tujuan mencerminkan daya beli masyarakat, ini berarti bahwa peningkatan daya beli masyarakat di negara tujuan akan meningkatkan volume ekspor kayu manis Indonesia. Hal ini sesuai dengan hasil penelitian yang dilakukan oleh Andari (2017) yang berjudul Analisis Pengaruh dan Tingkat Keberhasilan Perdagangan Indonesia dalam ASEAN-India Free Trade Agrrement (AIFTA), dimana produk domestik bruto per kapita negara tujuan 
berpengaruh signifikan dan positif terhadap ekspor.

Variabel jarak ekonomi antara Indonesia dengan negara tujuan memiliki pengaruh yang negatif, dimana setiap kenaikan satu persen jarak ekonomi akan menurunkan volume ekspor sebesar 2,65 persen. Variabel jarak ekonomi mencerminkan biaya ekspor, sehingga meningkatnya jarak ekonomi mengakibatkan biaya yang dikeluarkan negara tujuan menjadi lebih tinggi, karenanya peningkatan jarak ekonomi akan menurunkan permintaan ekspor kayu manis. Hal ini juga ditemukan dalam penelitian Inayah et al (2015) yang berjudul The analysis of export determinant of indonesian pepper in the international market, yaitu jarak ekonomi antara negara asal dengan negara tujuan berpengaruh negatif terhadap ekspor.

Variabel tarif memiliki pengaruh yang negatif terhadap volume ekspor cengkeh Indonesia, dimana setiap kenaikan tarif sebesar satu persen maka volume ekspor akan menurun sebesar 0,04 persen. Meningkatnya tarif ekspor di negara tujuan mengakibatkan penurunan volume ekspor cengkeh Indonesia ke negara tujuan. Berdasarkan penelitian yang dilakukan oleh Kis-Katos dan Sparrow (2015), ditemukan hasil yang serupa, yaitu keberadaan tarif di negara tujuan memberikan pengaruh yang negatif terhadap ekspor. Sehingga apabila tarif naik maka nilai ekspor akan turun, namun bila tarif mengalami penurunanan atau penghapusan maka nilai ekspor akan meningkat.

Pada variabel populasi dan harga ekspor, hasil analisis menunjukkan bahwa populasi negara tujuan cengkeh tidak berpengaruh signifikan terhadap volume cengkeh. Hal ini ditunjukkan dengan nilai probabilitas variabel populasi dan harga ekspor lebih besar dari taraf nyata, yaitu $0,31>0,05$ pada variabel populasi dan $0,20>0,05$ pada variabel harga ekspor.
Temuan ini serupa dengan temuan pada penelitian Irgandhini \& Firdaus (2014) yang berjudul Daya Saing dan Permintaan Ekspor Produk Biofarmaka Indonesia di Negara Tujuan Utama Periode 2003-2012.

Berdasarkan data yang digunakan, tidak signifikannya variabel populasi disebabkan karena tren volume eskpor cengkeh Indonesia selalu berfluktuasi di setiap negara pada setiap tahunnya, ada kalanya mengalami peningkatan namun ada kalanya mengalami penurunan. Sedangkan tren data populasi di negara tujuan terus meningkat. Selain itu, di pasar Vietnam yang merupakan pasar yang paling mendominasi ekspor pala, lawang dan kapulaga Indonesia, populasi penduduknya bukanlah populasi dengan jumlah terbesar maupun terkecil diantara semua negara yang diteliti. Hal ini menunjukkan bahwa jumlah populasi di negara tidak berpengaruh signifikan terhadap peningkatan ekspor cengkeh Indonesia di negara tujuan.

Pada variabel harga ekspor komoditas cengkeh, tidak signifikannya variabel harga ekspor menunjukkan bahwa kenaikan ataupun penurunan harga tidak signifikan memengaruhi volume ekspor cengkeh. Data volume ekspor dan harga ekspor (UN-Comtrade, 2017) menunjukkan bahwa kenaikan harga ekspor adakalanya diikuti dengan penurunan volume ekspor ke negara tujuan, namun adakalanya pula justru diikuti dengan kenaikan volume ekspor ke negara tujuan. Begitu pula dengan turunnya harga ekspor cengkeh, adakalanya penurunan harga eskpor diikuti dengan kenaikan volume ekspor cengkeh namun adakalanya pula justru diikuti dengan penurunan ekspor cenngkeh ke pasar tujuan.

Di pasar internasional, Indonesia merupakan salah satu produsen sekaligus eksportir cengkeh terbesar. Posisi ini menjadikan Indonesia sebagai salah satu negara penentu harga ekspor komoditas 
cengkeh. Hal inilah yang juga menjadi salah satu faktor yang menyebabkan fluktuasi harga ekspor cengkeh Indonesia yang diakibatkan oleh fluktuasi produksi cengkeh, tidak berpengaruh signifikan terhadap volume ekspor cengkeh Indonesia. Selain itu, pasar dunia mulai menyadari tentang fungsi cengkeh yang multiguna, sehingga konsumsi cengkeh terus mengalami peningkatan. Negara importir pun cenderung memilih untuk membeli komoditas cengkeh organik yang berkualitas, dimana cengkeh Indonesia adalah cengkeh yang diakui memiliki standar kualitas terbaik di pasar internasional.

\section{SIMPULAN DAN SARAN}

\section{Simpulan}

Ekspor sebagai salah satu komponen penting dalam perekonomian negara perlu menjadi salah satu fokus perhatian. Baiknya kinerja ekspor suatu negara akan berpengaruh positif bagi perekonomian Negara. Karenanya dalam rangka terus meningkatkan kinerja ekspor, negara perlu melakukan upaya pengembangan ekspor. Cengkeh sebagai salah satu produk Indonesia merupakan komoditas yang potensial dimanfaatkan untuk meningkatkan kinerja ekspor Indonesia.

Berdasarkan hasil penelitian dengan mempertimbangkan analisis RCA dan EPD disimpulkan bahwa pada umumnya cengkeh Indonesia di pasar utama memiliki daya saing yang kuat. Pasar yang memiliki potensi pengembangan pasar optimis adalah pasar Thailand, Pakistan dan Mesir. Sedangkan pasar yang memiliki potensi pengembangan pasar potensial adalah pasar Malaysia, Uni Emirat Arab, Vietnam, Saudi Arabia, Australia, Belanda, dan Pasar Jerman.

Adapun faktor-faktor yang berpengaruh signifikan terhadap ekspor komoditas cengkeh (HS 0907) adalah produk domestik bruto per kapita, jarak ekonomi dan tarif negara tujuan.

\section{Saran}

Sebagai salah satu upaya meningkatkan kinerja ekspor Indonesia, pemerintah dapat memanfaatkan cengkeh sebagai salah satu komoditas yang potensial untuk dikembangkan. Dalam rangka mengembangkan ekspor cengkeh, pemerintah dan eksportir perlu mengetahui dan memilih pasar mana saja yang menjadi prioritas utama untuk dikembangkan. Apabila pemerintah dan eksportir akan melakukan pengembangan ekspor komoditas cengkeh (HS 0907), pemerintah sebaiknya memprioritaskan pengembangan pada pasar Thailand, Pakistan dan Mesir. Sebagai prioritas kedua sebaiknya melakukan pengembangan ekspor di pasar Malaysia, Uni Emirat Arab, Vietnam, Saudi Arabia, Australia, Belanda, dan Jerman.

Sedangkan untuk melakukan pengembangan ekspor cengkeh Indonesia ke pasar lain, sebaiknya pemerintah mempertimbangkan faktor-faktor yang memengaruhi ekspor rempah Indonesia ke negara tujuan. Untuk ekspor komoditas cengkeh (HS 0907) pemerintah perlu memperhatikan faktor produk domestik bruto per kapita, jarak ekonomi dan tarif negara tujuan.

\section{DAFTAR PUSTAKA}

Andari W. 2017. Analisis Pengaruh dan Tingkat Keberhasilan Perdagangan Indonesia dalam ASEAN-India Free Trade Agreement (AIFTA). [Tesis]. Bogor (ID): Institut Pertanian Bogor.

Batiz FLR, Batiz LAR. 1994. International Finance and Open Economy Macroeconomics 2nd Edition. New York (USA): Macmillan Publishing Company. 
Basri F, Munandar H. 2010. Dasar-dasar Ekonomi Internasional: Pengenalan dan Aplikasi Metode Kuantitatif. Jakarta (ID) : Kencana.

[BI] Bank Indonesia. 2016. Produk Domestik Bruto. [internet]. [diunduh 2017 Januari 29]. Tersedia pada:http://www.bi.go.id/id/statistik/ metadata/seki/

Documents/14.\%20PDBProduk\%20

Domestik\%20Bruto\%20(IND)\%202 016.pdf.

[BPS] Badan Pusat Statistik. 2017. Nilai Ekspor Impor Indonesia (USD). [Internet]. [diunduh 2017 April 14]. Tersedia pada: https://www.bps.go.id/.

[BPS] Badan Pusat Statistik. 2017. Ekspor Indonesia ke 6 Negara Utama. [Internet]. [diunduh 2017 April 14]. Tersedia pada: https://www.bps.go.id/.

Elshehawy MA, Hongfang S, Rania AA. 2014. The factors affecting egypt's exports: evidence from gravity model analysis. Open Journal of Social Sciences. 1(2):138-148. http://dx.doi.org/10.4236/jss.2014.2 11020.

Estherhuizen, D. 2006. An Evaluation of The Competitiveness of the South African Agribusiness Sector. [Dissertation]. Pretoria (ZAF): University of Pretoria.

Head K. 2003. Gravity for Beginners. Canada (CAN) : University of British Columbia.

Hermawan, Iwan. 2015. Daya saing rempah indonesia di pasar asean periode pra dan pasca krisis ekonomi global. Buletin Ilmiah Litbang Perdagangan. 9(2):153-178.

Inayah I, Rina O, Heny KD. 2015. The analysis of export determinant of indonesian pepper in the international market. International Journal of Science and Research
(IJSR). 5(11):1856-1860. doi:10.21275/ART20163261.

Irgandhini AK, Firdaus M. Daya Saing Dan Permintaan Ekspor Produk Biofarmaka Indonesia di Negara Tujuan Utama Periode 2003-2012. Jurnal Manajemen dan Agribisnis. 11(3): 183-198.

[Kementan] Kementerian Pertanian Republik Indonesia. 2014 Outlook Komoditi Cengkeh. [internet]. [diunduh 2018 Februari 18]. Tersedia pada: pusdatin.setjen.pertanian.go.id/

Kis-Katos K, Sparrow R. 2015. Poverty, labour markets and trade liberalization in Indonesia. Journal of Development Economics. 3878(15).1-45.

Krugman PR, Obstfeld M. 2003. International Economics Theory and Policy. New York (USA) : Addison Wesley Longman, Inc.

Mankiw N G. 2000. Teori Makroekonomi. Jakarta (ID): Erlangga.

Porter, ME. 1994. Keunggulan Bersaing. Jakarta (ID): Binarupa Aksara.

Tambunan, Tulus. 2001. Perdagangan Internasional dan Neraca Pembayaran-Teori dan Temuan Empiris. Jakarta (ID): PT Pustaka LP3ES Indonesia.

Tarman, Dewi K, Hari W, Umar F, Naufa M, Bambang SW. 2011. Kajian Kebijakan Pengembangan Diversifikasi Pasar dan Produk Ekspor. Laporan Akhir Kajian Kementerian Perdagangan Republik Indonesia. [Internet] [diunduh 2017 Maret 26]. Tersedia pada: www.kemendag.go.id/files/pdf/2014 /01/06/ Full-Report-KajianDiversifikasi.pdf.

Telaumbanua E. 2012. Analisis determinan ekspor Provinsi Sumatera Utara: Pendekatan Gravity Model. Quantitative Economics Journal. 2(2): 35-52. 
[UN-Comtrade] United Nations Commodity Trade. 2017 Statistics Database. [Internet]. [diunduh 2017 April 14]. Tersedia pada: https://comtrade.un.org/data

Yuniarti D. 2007. Analisis determinan perdagangan bilateral indonesia pendekatan gravity model. Jurnal Ekonomi Pembangunan Kajian Ekonomi Negara Berkembangs. 12 (2):99-109. 